\title{
Analisis Tingkat Kualitas Pelayanan Nasabah Pegadaian Syariah Cabang Veteran Purwakarta
}

\author{
Saepul Bahri* \\ Prodi Perbankan Syariah STIES Indonesia Purwakarta \\ Jl. Veteran No. 150-152 Ciseureuh Purwakarta 41118 Jawa Barat Indonesia \\ ${ }^{1}$ saepulbacktonature@gmail.com
}

\begin{abstract}
Intisari- Berdasarkan hasil penelitian dan pembahasan tentang Analisis Tingkat Kualitas Pelayanan Nasabah Pegadaian Syariah Cabang Veteran Purwakarta, maka dapat ditarik beberapa kesimpulan sebagai berikut : (1) Dari bukti fisik yang ada di Pegadaian Syariah Cabang Veteran Purwakarta masyarakat menganggap bahwa kondisi gedung yang dimiliki dan cara karyawan dalam berpenampilan sudah cukup baik, serta promosi yang dilakukan oleh pihak pegadaian sudah dapat menarik minat masyarakat untuk bertransaksi di pegadaian; (2) Keandalan pegadaian syariah dalam melakukan pelayanan tepat waktu dinilai sudah cukup baik, sebagian nasabah pun menyatakan puas. Selain itu pegadain syariah juga tidak pernah ingkar janji, dan selalu berusaha membantu memecahkan permasalahan yang dihadapi nasabahnya pada saat transaksi, serta selalu teliti dalam melakukan pencatatan data; (3) Daya tanggap pegadaian syariah merupakan kemauan untuk membantu dan memberikan pelayanan yang cepat dan tepat kepada nasabah, dengan penyampaian informasi yang jelas serta kesediaannya dalam menyambut nasabah dinilai nasabah Pegadaian Syariah Cabang Veteran Purwakarta sebagai hal yang dianggap paling penting dan mempunyai pengaruh yang paling dominan untuk meningkatkan kepuasan nasabah; (4) Jaminan dan kepastian yang diberikan pegadaian syariah cabang Veteran Purwakarta yaitu sifat karyawan yang dapat dipercaya, pengetahuan yang memadai mengenai masalah produk pegadaian syariah, serta sikap sopan karyawan pegadaian syariah terhadap nasabah yang ingin bertransaksi yang di nilai masyarakat sudah baik; (5) Perhatian yang diberikan oleh pegadaian syaariah cabang Veteran Purwakarta kepada nasabah pegadaian syariah mendapatkan respon yang baik. Nasabah menganggap bahwa pihak pegadaian mampu memberikan kemudahan dalam melakukan transaksi, dapat memahami kebutuhan nasabahnya, serta memberikan perhatian pribadi kepada nasabahnya. Dari kelima dimensi pelayanan diketahui bahwa dimensi pelayanan yang dinilai paling baik menurut persepsi responden adalah dimensi Tangible (bukti fisik) yaitu mencapai $79 \%$. Sedangkan yang penilaiannya rendah menurut persepsi responden yaitu pada dimensi Reliabiliti (keandalan) yaitu sebesar $76.5 \%$. Kata kunci- Kualitas Pelayanan Nasabah, Pegadaian Syariah.
\end{abstract}

Abstract- Based on the results of the research and discussion on the Level of Quality Analysis of the Syariah Pawnshop Customer Service at the Veteran Purwakarta Branch, some conclusions can be drawn as follows: (1) From the physical evidence at the Pegadaian Syariah Branch Veterans Purwakarta the community considers that the condition of the building owned and the way employees are in look good enough, and the promotion carried out by the pawnshop can attract the public to transact at pawnshops; (2) The reliability of sharia pawnshops in conducting services on time is considered to be good enough, some customers are satisfied. In addition, sharia entrepreneurs also never break promises, and always try to help solve problems faced by their customers at the time of the transaction, and always be careful in recording data; (3) The responsiveness of sharia pawnshops is a willingness to assist and provide prompt and appropriate services to customers, with clear information delivery and willingness to welcome customers to be assessed by the Veteran Purwakarta Branch of Pawnshop customers as considered to be the most important and have the most dominant influence to increase customer satisfaction; (4) Guarantees and certainty given by the branch of Veterans Purwakarta sharia pawnshop, namely the trustworthy nature of employees, adequate knowledge of the problem of sharia pawnshop products, as well as the polite attitude of sharia pawnshop employees towards customers who wish to transact which the community values are good; (5) Attention given by the Veteran Purwakarta branch pawnshop to sharia pawnshop customers get a good response. The customer considers that the pawnshop is able to provide convenience in conducting transactions, can understand the needs of its customers, and provide personal attention to its customers. Of the five service dimensions it is known that the dimensions of service that are considered the best according to respondents' perceptions are the Tangible dimension (physical evidence) which is $79 \%$. While the assessment is low according to the respondent's perception that is in the dimensions of Reliability (reliability) that is equal to $76.5 \%$.

Keywords - Quality of Customer Service, Pegadaian Syariah.

\section{Pendahuluan}

Persaingan bisnis di masa sekarang semakin ketat, baik di industri perbankan maupun di lembaga keuangan lainnya. Persaingan antar lembaga keuangan tersebut dalam rangka mendapatkan kepercayaan dari masyarakat atau deposan. Ketatnya persaingan tersebut menuntut pengelola lembaga keuangan untuk sangat berhati-hati demi kontinuitas dan meningkatkannya prestasi perusahaan. ${ }^{1}$ Untuk memenangkan persaingan pengelola lembaga keuangan harus memperhatikan kebutuhan dan keinginan nasabahnya, serta memenuhi harapan mereka, sehingga mampu memberikan pelayanan kepada nasabahnya melalui penyampaian produk dan jasa yang berkualitas dengan tetap memperhatikan kebutuhan dan keinginan nasabah. Dalam hal ini perusahaan harus lebih kreatif dalam menciptakan produk yang bisa memuaskan daan memenuhi kebutuhan nasabah. ${ }^{2}$

Keberhasilan perusahaan jasa tergantung pada kualitas pelayanan yang diberikan kepada nasabah serta kemampuan petugas dalam memberikan pelayanan dan menjelaskan produk-produk yang ditawarkan sesuai dengan kebutuhan dan harapan nasabah. Dengan pelayanan yang berkualitas maka nasabah akan merasa puas sehingga nasabah akan mempertahankan serta menambah loyalitas terhadap 


\section{EKSISBANK Vol. 2 No. 2 Desember 2018}

perusahaan jasa tersebut. Perusahaan jasa harus berusaha memberikan pelayanan yang berkualitas untuk mewujudkan kepuasan nasabahnya, sebab jika tidak mencapai kepuasan maka nasabah akan meninggalkan perusahaan dan pindah ke perusahaan pesaing. ${ }^{3} \mathrm{Hal}$ ini akan berakibat menurunnya laba bahkan menimbulkan kerugian, oleh sebab itu perusahaan yang bergerak di bidang jasa memberikan kepuasan kepada nasabah merupakan hal yang sangat penting akan keberadaannya karena nasabah akan menyebar luaskan berita akan kepuasan yang mereka alami, sehingga akan menaikkan reputasi dari perusahaan yang bergerak di bidang jasa tersebut. ${ }^{4}$

Saat ini lembaga keuangan memiliki peran yang sangat penting, karena hampir setiap kegiatan tidak mungkin terlepas dari peran lembaga keuangan. Lembaga keuangan merupakan salah satu faktor pendorong pertumbuhan ekonomi negara. Salah satunya adalah pegadaian sebagai Badan Usaha Milik Negara (BUMN) yang merupakan lembaga keuangan non bank yang bergerak dalam bidang penyaluran kredit atas dasar hukum gadai. Seperti dalam QS. Al-Baqarah ayat 283 :

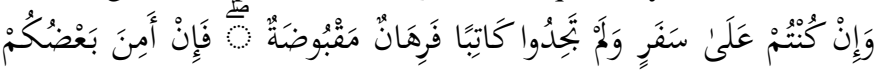

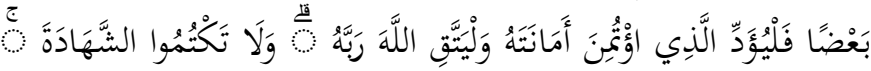

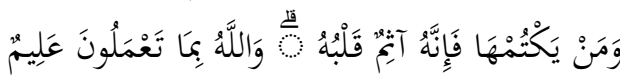

"Jika kamu dalam perjalanan (dan bermu"amalah tidak secara tunai) sedang kamu tidak memperoleh seorang penulis, maka hendaklah ada barang tanggungan yang dipegang (oleh yang berpihutang). Akan tetapi jika sebagian kamu mempercayai sebagian yang lain, maka hendaklah ia bertakwa kepada Allah Tuhannya; dan janganlah kamu (para saksi) menyembunyikan persaksian. Dan barang siapa yang menyembunyikannya, maka sesungguhnya ia adalah orang yang berdosa hatinya; dan Allah maha mengetahui apa yang kamu kerjakan."5

Dalam ketentuan transaksi yang dikenal sebagai gadai, peraturan yang ada memang membatasi transaksi itu pada harta bergerak saja. Hanya saja inti dari gadai itu adalah adanya transaksi utang dengan menjadikan harta sebagai jaminan. Namun ada pula harta itu merupakan harta tak bergerak seperti rumah, tanah, bangunan, mesin, dan sebaginya. Ada kondisi dimana barang rahn yang diagunkan itu memerlukan perawatan dan kalau tidak dirawat maka akan rusak atau binasa, seperti agunan dalam bentuk hewan. Dalam hal ini Abu Hurairah menuturkan dari Nabi saw, bersabda :

"Apabila ada ternak digadaikan, punggungnya boleh dinaiki oleh orang yang menerima gadai, karena ia telah mengeluarkan biaya menjaganya. Apabila ternak itu digadaikan, air susunya yang deras boleh diminum oleh orang yang menerima gadai, karena ia telah mengeluarkan biaya menjaganya. Kepada orang yang naik dan minum, ia harus mengeluarkan biaya perawatannya."(HR.Jamaah, kecuali Muslim dan An-Nasa ${ }^{\text {ee }}$ i). ${ }^{6}$

Pegadaian menjalankan fungsi sebagai pengganti bank yaitu penyalur pinjaman dana ke masyarakat, oleh karena itu pegadaian dituntut harus menunjukan kinerja yang baik agar bisa menjadi salah satu lembaga keuangan non bank yang dapat diandalkan di masa sekarang dan di masa yang akan datang.
Sumber dana yang selama ini masih dipergunakan untuk keperluan penyaluran uang pinjaman atas dasar hukum gadai dominan dengan sistem bunga (konvensional). Sementara bunga dalam lembaga keuangan menurut pandangan sebagian besar ulama adalah identik dengan riba. Ekonomi yang berbasis bunga tidak hanya dipraktekkan dalam lembaga ekonomi dan keuangan seperti bank, tetapi juga lembaga non bank. ${ }^{7}$

Seiring dengan lahirnya Undang-Undang perbankan yang mendukung eksisnya lembaga ekonomi dan keungan syariah, sejumlah individu yang peka terhadap permasalahan sosial ekonomi umat memberikan respon positif yang secara kreatif mengembangkan ide untuk berdirinya lembaga-lembaga keuangan syariah bukan bank seperti pegadaian yang berbasis syariah. Majelis Ulama Indonesia telah mengeluarkan Fatwa No.25/DSN-MUI/VI/2012 tentang Rahn sebagai salah satu upaya untuk mengakomodasikan kebutuhan masyarakat muslim dalam bidang jasa keuangan lembaga non bank. ${ }^{8}$

Di Indonesia, terbentuknya pegadaian syariah bekerja sama dengan perum pegadaian yang membentuk Unit Layanan Gadai Syariah (ULGS) dimana rahn adalah perjanjian penyerahan barang atau harta sebagai jaminan berdasarkan hukum gadai berupa emas, perhiasan, kendaraan atau barang yang berharga lainnya. Rahn atau pegadaian dipandang sebagai salah satu bentuk pelayanan yang bisa dioperasikan berdasarkan prinsip syariah.

Dalil yang dijadikan landasan hukum oleh Dewan Syariah Nasional tentang pegadaian yang sesuai dengan fatwa DSN No.25/DSN-MUI/III/2002 adalah :

Hadits Riwayat Bukhari dan Muslim

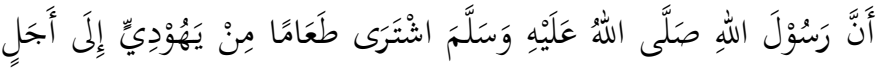

$$
\begin{aligned}
& \text { وَرَهَنَهُ دِزْعَا مِنْ حَدِيْدِ. }
\end{aligned}
$$

"sesungguhnya Rasulullah Saw. pernah membeli makanan dengan berhutang dari seorang yahudi, dan nabi menggadaikan sebuah baju besi kepadanya."9

Nasabah yang semakin meningkat menuntut pihak pegadaian syariah cabang Veteran Purwakarta untuk terus meningkatkan kinerja karyawannya demi menciptakan kepuasan bagi nasabahnya. Selain itu peningkatan jumlah nasabah dapat berpengaruh kepada banyak nya keinginan dan harapan nasabah akan produk (jasa) yang lebih baik dari sebelumnya. Ketika pelayanan dan produk (jasa) kurang baik akan berpengaruh terhadap tingkat jumlah nasabah di pegadaian tersebut, sehingga pihak pegadaian harus lebih berusaha memberikan yang terbaik untuk memberikan kepuasan kepada nasabahnya. Peningkatan dan penurunan nasabah Pegadaian Syariah Cabang Veteran Purwakarta dapat dilihat pada grafik berikut.

\footnotetext{
${ }^{3}$ J Supranto, Pengukuran Tingkat Kepuasan Pelanggan Untuk Menaikan Pangsa Pasar, (Jakarta: PT Rineka Cipta, 2011), hlm.2.

${ }^{4}$ Ibid, hlm.4.

${ }^{5}$ Syahida, Qur'an Terjemah, (Bandung: Quranidea, 2007), hlm.49

${ }^{6}$ Yahya Abdurahman, Pegadaian dalam Pandangan Syariah, (Bogor: AlAzhar Press, 2012), hlm.52.
} 


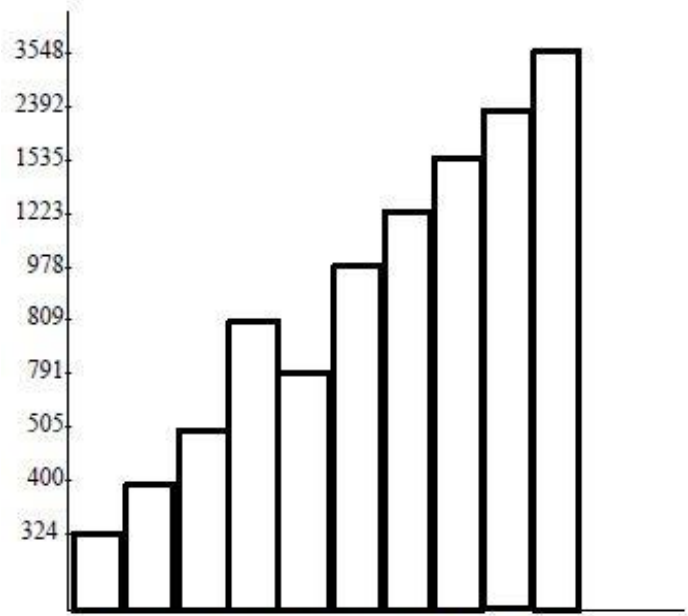

Jan Feb Mar Apr Mei Jun Jul Aug Sep Okt

Sumber: Pegadaian Syariah Cabang Veteran Purwakarta ${ }^{10}$

Untuk memberikan kepuasan kepada nasabahnya pihak pegadaian syariah harus senantiasa memperhatikan komunikasi serta dengan menjalin kegiatan pelayanan prima yang dapat merangsang pembelian dan kepuasan nasabah. Jasa pelayanan yang dilaksanakan perusahaan tersebut dalam upaya untuk memberikan rasa kepuasan, menimbulkan kepercayaan kepada pihak nasabah, yang merupakan prioritas utama dari penerapan pelayanan prima, karena kepuasan nasabah adalah tingkat perasaan seseorang setelah melihat dan merasakan hasil kinerja yang ia dapatkan.

Kualitas pelayanan harus tetap dijaga dan ditingkatkan untuk meningkatkan kepuasan nasabah. Kualitas pelayanan merupakan salah satu faktor yang selama ini mempengaruhi kepuasan nasabah secara umum, dan menjadi faktor utama dalam kepuasan nasabah di perusahaan jasa. Dengan demikian dapat disimpulkan bahwa untuk mencapai tingkat kepuasan nasabah suatu lembaga atau perusahaan harus meningkatkan kualitas pelayanan serta memenuhi harapan-harapan masyarakat.

Dengan uraian diatas maka sangat menarik untuk menjadikan pegadaian syariah sebagai objek penelitian skripsi dengan judul " Analisis Tingkat Kualitas Pelayanan Nasabah Pegadaian Syariah Cabang Veteran Purwakarta”.

\section{METODOLOGI}

Penulis menggunakan beberapa metode penelitian, yaitu metode penelitian deskriptif dan metode penelitian survey. Pengertian dari kedua metode tersebut adalah sebagai berikut : Peneletian deskriptif merupakan penelitian dimana pengumpulan data untuk mengetes pertanyaan penelitian yang berkaitan dengan keadaan dan kejadian sekarang. Pengertian metode penelitian deskriptif, peneliti tidak melakukan manipulasi variabel dan tidak menetapkan peristiwa yang akan terjadi, dan biasanya menyangkut peristiwa-peristiwa yang saat sekarang terjadi. Dengan penelitian deskriptif ini peneliti memungkinkan untuk menjawab pertanyaan penelitian yang berkaitan dengan hubungan variabel atau asosiasi, dan juga mencari hubungan komparasi antar variabel. ${ }^{11}$

${ }^{10}$ Hasil Wawancara kepada : Adhy Prasasti Putra, Pegadaian Syariah Cabang Veteran Purwakarta, Senin, 19-09-2016, 08.30 Wib

11 Sukardi, Metode Penelitian Pendidikan, (Jakarta: PT Bumi Aksara, 2013), hlm.158.

${ }^{12}$ Sugiyono, Metode Penelitian Bisnis, (Bandung: Alfabeta CV, 2010),
Pengertian metode survey digunakan untuk mendapatkan data dari tempat tertentu yang alamiah (bukan buatan), tetapi peneliti melakukan perlakuan dalam pengumpulan data, misalnya dengan mengedarkan kuesioner test, wawancara terstruktur dan sebagainya (perlakuan tidak seperti dalam eksperimen). Metode penelitian naturalistik/ kualitatif, digunakan untuk meneliti pada tempat yang alamiah, dan penelitian tidak membuat perlakuan, karena peneliti dalam mengumpulkan data bersifat emic, yaitu berdasarkan pandangan dari sumber data, bukan pandangan peneliti. ${ }^{12}$

Sumber Data penelitian ini termasuk penelitian lapangan, karena data-data yang diperoleh dari hasil pengamatan langsung dari nasabah Pegadaian Syariecah Cabang Veteran Purwakarta. Data yang digunakan dalam penelitian adalah data primer dan data sekunder. Data primer adalah data yang langsung diperoleh oleh pengumpul data. Sedangkan data sekunder adalah data yang tidak diperoleh secara langsung oleh pengumpul data, misalnya lewat orang lain atau lewat dokumen. ${ }^{13}$

Teknik pengumpulan data yang digunakan penulis adalah sebagi berikut : (1) Kuesioner merupakan teknik pengumpulan data yang dilakukan dengan cara memberi seperangkat pertanyaan atau pernyataan tertulis kepada nasabah untuk dijawabnya. Kuesioner dibuat dengan menggunakan pertanyaan terbuka, yaitu terdiri dari pertanyaan-pertanyaan untuk menjelaskan identitas. Dan pertanyaan tertutup, yaitu pertanyaan yang meminta responden untuk memilih salah satu jawaban yang tersedia dari setiap pertanyaan; (2) Wawancara Pengumpulan data dilakukan dengan cara melakukan wawancara langsung dengan pihak yang berkepentingan di perusahaan. Metode ini bertujuan untuk memperoleh data mengenai gambaran umum perusahaan; (3) Studi Pustaka dilakukan dengan mempelajari dan mengambil data literatur terkait sumber-sumber lain yang dianggap dapat memberikan informasi mengenai penelitian ini.

Populasi dan Sampel, populasi adalah wilayah generalisasi yang terdiri atas : obyek/ subyek yang mempunyai kualitas dan karakteristik tertentu yang ditetapkan oleh peneliti untuk dipelajari dan kemudian ditarik kesimpulannya. ${ }^{14}$ Populasi pada penelitian ini adalah nasabah pegadaian syariah cabang Veteran Purwakarta yaitu 3548 nasabah.

Sampel adalah bagian dari jumlah dan karakteristik yang dimiliki oleh populasi tersebut. ${ }^{15}$ 15Pengambilan sampel (sampling) adalah proses memilih sejumlah elemen secukupnya dari populasi, sehingga penelitian terhadap sampel dan pemahaman tentang sifat atau karakteristiknya akan membuat kita dapat menggeneralisasikan sifat atau karakteristik tersebut pada elemen populasi. Bila dalam penelitian akan melakukan analisis dengan multivariate (kolerasi atau regresi ganda misalnya), maka jumlah anggota sampel minimal 10 kali dari jumlah variabel yang diteliti. Jumlah sampel yang diambil dalam penelitian ini sebanyak 5 variabel x $10=50$ nasabah Pegadaian Syarie ah Cabang Veteran Purwakarta. Metode sampling yang digunakan dalam penelitian ini adalah Purposive Sampling dan Accidental sampling. Purposive Sampling adalah teknik penentuan sampel dengan pertimbangaan tertentu. Accidental sampling adalah hlm.11.

13 Sugiyono, Metodologi Penelitian Kuantitatif, Kualitatif Dan R\&D, (Bandung: Alfabeta, 2008), hlm.225.

${ }^{14}$ Sugiyono, Op.Cit., hlm.115.

${ }^{15}$ Ibid, hlm.116. 
siapa saja yang melakukan transaksi yang ditemui untuk dijadikan sampel. ${ }^{16}$

Teknik Analisa Data, menurut Kamus bahasa Indonesia analisa adalah penyelidikan kimia dengan menguraikan sesuatu zat-zat bagiannya, penelitian sesuatu masalah, karangan untuk mengetahui latar belakang dan duduk permasalahan. ${ }^{17}$ Dalam penelitian kualitatif, data yang diperoleh dari berbagai sumber, dengan menggunakan teknik pengumpulan data yang bermacam-macam (triangulasi), dan dilakukan secara terusmenerus sampai datanya jenuh. Dengan pengamatan yang terus-menerus tersebut mengakibatkan variasi data tinggi sekali. Data yang diperoleh pada umumnya adalah data kualitatif (walaupun tidak menolak data kuantitatif), sehingga teknik analisis data yang digunakan belum ada polanya yang jelas. Oleh karena itu, sering mengalami kesulitan dalam melakukan analisis. $^{18}$

Analisis data dalam penelitian kualitatif dilakukan sejak sebelum memasuki lapangan, selama di lapangan, dan setelah selesai lapangan. Namun dalam penelitian kualitatif, analisis data lebih difokuskan selama proses di lapangan bersamaan dengan pengumpulan data. ${ }^{19}$ Untuk dapat mengetahui indikator pelayanan mana yang lebih baik menurut persepsi responden maka pertama-tama ditentukan jumlah skor dari setiap butir pertanyaan dengan cara mengalikan skor jawaban dengan jumlah responden yang memilih jawaban tersebut kemudian dijumlahkan. Selanjutnya dilakukan perhitungan skor ideal dengan cara mengalikan skor jawaban tertinggi dengan butir pertanyaan pada masing-masing indikator dan jumlah responden. Skor ideal adalah skor yang ditetapkan dengan asumsi bahwa setiap responden pada setiap pertanyaan memberi jawaban dengan skor tertinggi. Kemudian membagikan jumlah nilai dari setiap pertanyaan dengan skor ideal. $^{20}$

\section{Pembahasan dan Penomena}

\section{A. Pengertian Kualitas}

Kualitas (quality) adalah totalitas fitur dan karakteristik produk atau jasa yang bergantung pada kemampuannya untuk memuaskan kebutuhan yang dinyatakan atau tersirat. Kita dapat mengatakan penjual telah menghantarkan kualitas ketika produk atau jasanya memenuhi atau melebihi ekspektasi pelanggan. ${ }^{21}$ Kualitas total adalah tugas semua orang, seperti halnya pemasaran. Pemasar memainkan beberapa peran dalam membantu perusahaan mereka mendefinisikan dan menghantarkan barang dan jasa berkualitas tinggi kepada pelanggan sasaran. Peran tersebut antara lain sebagai

1. Mereka mengemban tanggung jawab utama untuk mengidentifikasi kebutuhan dan persyaratan pelanggan dengan benar.

2. Mereka harus mengkomunikasikan ekspektasi pelanggan dengan tepat kepada perancang produk.

3. Mereka harus memastikan bahwa pesanan pelanggan dipenuhi dengan tepat dan sesuai jadwal.

\footnotetext{
${ }^{16}$ Sugiyono, Op Cit., hlm.130

${ }^{17}$ Ali Muhammad, Kamus Lengkap Bahasa IndonesiaModeren, (Jakarta: Pustaka Amani, Anonimouse), hlm.10.

${ }^{18}$ Sugiono, Metode Penelitian Kombinasi, (Bandung: Alfabeta CV, 2015), hlm.331

${ }^{19}$ Sugiyono, Op Cit., hlm.428

${ }^{20}$ Sugiyono, Op Cit., hlm.234.

${ }^{21} 21$ Philip Kotler dan Kevin Lane Keller, Manajemen Pemasaran, (Jakart: Erlangga, 2009), hlm.143.
}

4. Mereka harus memeriksa bahwa pelanggan menerima instruksi yang benar, pelatihan, dan bantuan teknis dalam penggunaan produk.

5. Mereka harus tetap berhubungan dengan pelanggan setelah penjualan untuk memastikan bahwa mereka puas dan tetap puas.

6. Mereka harus mengumpulkan ide pelanggan tentang perbaikan produk dan jasa dan menyalurkan ide-ide tersebut ke departemen yang tepat.

\section{B. Pengertian Pelayanan}

Menurut Ivancevich, Lorenzi, Skinner dan Crosby, pelayanan adalah produk-produk yang tidak kasat mata (tidak dapat diraba) yang melibatkan usahausaha manusia dan menggunakan peralatan. Menurut Gronroos, pelayanan adalah suatu aktivitas atau serangkaian aktivitas yang bersifat tidak kasat mata (tidak dapat diraba) yang terjadi sebagai akibat adanya interaksi antara konsumen dengan karyawan atau halhal yang disediakan oleh perusahaan pemberi pelayanan yang dimaksudkan untuk memecahkan permasalahan konsumen atau pelanggan. ${ }^{23}$

Karakteristik yang dipakai untuk memahami pengertian pelayanan adalah sebagai berikut: ${ }^{24}$

1. Konsumen memiliki kenangan. Pengalaman atau memori tersebut tidak bisa dijual atau diberikan kepada orang lain.

2. Tujuan penyelenggaraan pelayanan adalah keunikan. Setiap konsumen dan setiap kontak adalah spesial.

3. Suatu pelayanan terjadi saat tertentu, ini tidak dapat disimpan di gudang atau dikirimkan contohnya.

4. Konsumen adalah rekanan yang terlibat dalam proses produksi

5. Konsumen melakukan kontrol kualitas dengan cara membandingkan harapannya dengan pengalamannya.

6. Jika terjadi kesalahan, satu-satunya cara yang bisa dilakukan untukmemperbaiki adalah meminta maaf.

7. Moral karyawan berperan sangat menentukan.

\section{Kualitas Pelayanan}

Menurut Parasuraman, kualitas pelayanan (service quality) adalah suatu konsep secara tepat mewakili inti dari kinerja suatu jasa, yaitu perbandingan terhadap keterandalan (excelince) dalam servise encounter yang dilakukan oleh konsumen. Pengembangan, pemeliharaan dan perbaikan kualitas pelayanan dari suatu lembaga dapat menimbulkan kepuasan pada semua pelanggan. ${ }^{25}$

Dalam mengukur kualitas pelayanan yang baik Zeithaml, Parasuraman dan Berry mengacu pada 5 indikator, ${ }^{26}$ yaitu:

1. Tangibles atau ketampakan fisik, artinya petampakan fisik dari gedung, peralatan, pegawai, dan fasilitas-fasilitas lain yang dimiliki oleh provider.

2. Reliability atau reliabilitas adalah kemampuan untuk menyelenggarakan pelayanan yang dijanjikan secara akurat.

\footnotetext{
${ }^{22}$ Ibid, hlm.144.

${ }^{23}$ Ratminto dan Atik Septi Winarsih, Manajemen Pelayanan, (Yogyakarta: Pustaka Pelajar, 2005), hlm.2.

${ }^{24}$ Ibid, hlm.3.

${ }^{25}$ Malayu S. P. Hasibuan, Manajemen Sumber Daya Manusia, (Jakarta: CV Haji Masagung, 1994), hlm.244.

${ }^{26}$ Ratminto dan Atik Septi Winarsih, Op.Cit., hlm.175.
} 


\section{EKSISBANK Vol. 2 No. 2 Desember 2018}

3. Responsiveness atau responsivitas adalah kerelaan untuk menolong customers daan menyelenggarakan pelayanan secara ikhlas.

4. Assurance atau kepastian adalah pengetahuan dan kesopanan para pekerja dan kemampuan mereka dalam memberikan kepercayaan kepada customers.

5. Empathy adalah perlakuan atau perhatian pribadi yang diberikan oleh providers kepada customers.

D. Produk yang ditawarkan Pegadaian Syariah Cabang Veteran Purwakarta

Pembiayaan Rahn dari pegadaian syariah aadalah solusi tepat kebutuhan dana cepat yang sesuai syariah. Cepat prosesnya, aman penyimpanannya. Barang jaminan berupa emas perhiasan,emas batangan, handphone, laptop, barang elektronik lainnya,sepeda motor, mobil atau barang bergerak lainnya. Model bisnis gadai syariah dapat dilihat di bagan berikut. $^{27}$

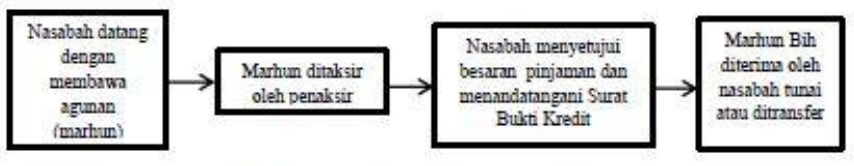

Bagan 3.2. Model Bisnis Gadai Syariah

Arrum adalah pembiayaan syariah untuk pengembangan Usaha Mikro Kecil dan Menengah (UMKM) dengan jaminan BPKB kendaraan bermotor.

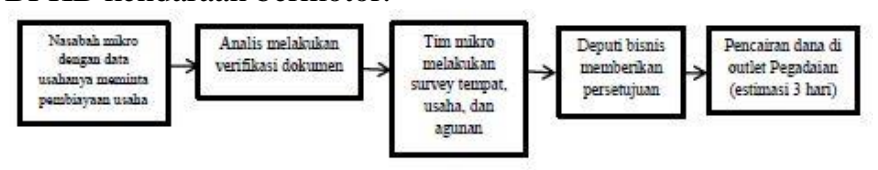

Bagan. 3.3. Model Bisnis Arrum

Amanah adalah pembiayaan kepemilikan kendaraan bermotor kepada karyawan tetap dan pengfusaha mikro dengan prinsip syariah.

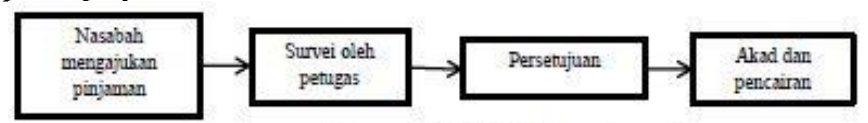

Bagan. 3.4. Model Bisnis Amanah

Tabungan emas adalah layanan pembelian dan penjualan emas dengan fasilitas titipan dengan harga yang terjangkau. Layanan ini memberikan kemudahan kepada masyarakat untuk berinvestasi emas.

\section{E. Analisis Data Responden}

Jumlah nasabah pegadaian syariah cabang Veteran purwakarta yang menjadi responden dalam penelitian ini adalah 50 nasabah yang ditemui selama dua minggu dan seluruh kuesioner kembali serta layak untuk di analisa. Berdasarkan kuesioner tersebut dapat diidentifikasi karakteristik responden dalam penelitian ini berdasarkan empat karakteristik yaitu jenis kelamin, umur, pendidikan terakhir, dan pekerjaan. Secara rinci karakteristik dari responden/ nasabah pegadaian syarian cabang Veteran Purwakarta dapat di jelaskan sebagai berikut.

Tabel 3.1

Karakteristik Jenis Kelamin

\begin{tabular}{|c|c|c|c|}
\hline No & Jenis kelamin & Jumlah & Persentase \\
\hline 1 & Pria & 26 & $52 \%$ \\
\hline 2 & Wanita & 24 & $48 \%$ \\
\hline & TOTAL & 50 & $100 \%$ \\
\hline
\end{tabular}

Berdasarkan tabel diatas diketahui bahwa dari 50 responden/ nasabah pegadaian syariah cabang Veteran Purwakarta terdiri dari pria $52 \%$ dan nasabah wanita $48 \%$.

Tabel 3.2

Karakteristik Umur

\begin{tabular}{|c|c|c|c|}
\hline No & Umur & Jumlah & Persentase \\
\hline 1 & $<20$ Tahun & 3 & $6 \%$ \\
\hline 2 & $20-29$ Tahun & 9 & $18 \%$ \\
\hline 3 & $30-39$ Tahun & 14 & $28 \%$ \\
\hline 4 & $40-49$ Tahun & 12 & $24 \%$ \\
\hline 5 & $>50$ Tahum & 12 & $24 \%$ \\
\hline \multicolumn{2}{|c|}{ TOTAL } & 50 & $100 \%$ \\
\hline \multicolumn{2}{|c|}{ Sumber : Data Primer (Kuesioner) }
\end{tabular}

Tabel diatas menjelaskan bahwa nasabah pegadaian syariah cabang Veteran Purwakarta yang menjadi responden paling banyak adalah umur 30-39 tahun sebesar 28\%, kemudian diikuti oleh nasabah yang berumur 40-49 tahun sebesar $24 \%$, umur $>50$ tahun sebesar 24\%, umur 20-29 tahun sebesar $18 \%$. Sedangkan untuk umur $<20$ tahun sebesar $6 \%$.

Tabel 3.3

Karakteristik Pendidikan

\begin{tabular}{|c|c|c|c|}
\hline No & Pendidikan Terakhir & Jumlah & Persentase \\
\hline 1 & SMP & 14 & $28 \%$ \\
\hline 2 & SMA & 15 & $30 \%$ \\
\hline 3 & Akademi/ Diploma & 9 & $18 \%$ \\
\hline
\end{tabular}

\begin{tabular}{|c|c|c|c|}
\hline 4 & Sarjana (S1) & 12 & $24 \%$ \\
\hline 5 & Sarjana (S2) & 0 & $0 \%$ \\
\hline 6 & Doktor (S3) & 0 & $0 \%$ \\
\hline \multicolumn{2}{|r|}{ TOTAL } & 50 & $100 \%$ \\
\hline
\end{tabular}

Sumber : Data Primer (Kuesioner)

Berdasarkan tabel diatas dapat diketahui bahwa jumlah responden/ nasabah pegadaian syariah cabang Veteran Purwakarta paling banyak pendidikan terakhirnya yaitu SMA

\footnotetext{
${ }^{27}$ Brosur tentang produk rahn ( gadai syariah), Pegadaian Syariah Cabang Veteran Purwakarta, Senin, 19-09-2016 pukul: 08.30 WIB
} 


\section{EKSISBANK Vol. 2 No. 2 Desember 2018}

sebanyak 15 nasabah sebesar 30\%, kemudian diikuti SMP sebanyak 14 nasabah sebesar $28 \%$, Sarjana (S1) sebanyak 12 nasabah sebesar 24\%, dan Akademi/Diploma sebanyak 9 nasabah sebesar 18\%. Sedangkan untuk sarjana (S2) dan Doktor (S3) tidak ada.

Tabel 3.4

Karakteristik Pekerjaan

\begin{tabular}{|c|c|c|c|}
\hline No & Pekerjaan & Jumlah & Persentase \\
\hline 1 & Pelajar/Mahasiswa & 0 & $0 \%$ \\
\hline 2 & PNS & 6 & $12 \%$ \\
\hline 3 & Pengusaha & 3 & $6 \%$ \\
\hline 4 & Pedagang & 15 & $30 \%$ \\
\hline 5 & Pegawai Swasta & 12 & $24 \%$ \\
\hline 6 & Lain-lain & 14 & $28 \%$ \\
\hline & TOTAL & 50 & $100 \%$ \\
\hline
\end{tabular}

Sumber : Data Primer (Kuesioner)

Tabel diatas menjelaskan bahwa status pekerjaan responden/ nasabah pegadaian syariah cabang Veteran Purwakarta sebagian besar sebagai pedagang sebesar $30 \%$, kemudian sebagai ibu rumah tangga (lain-lain) sebesar $28 \%$ Pegawai swasta sebesar 24\%, dan PNS sebesar $12 \%$. Sedangkan untuk Pengusaha sebesar 3\% dan untuk pelajar/ mahasiswa tidak ada.

\section{F. Deskripsi Data Penelitian}

1. Tangible (Bukti fisik)

Tabel 3.5

Kondisi Gedung yang dimiliki

\begin{tabular}{|c|c|c|c|}
\hline & Frekuensi & Persentase & Skor \\
\hline Sangat Baik (5) & 24 & $48 \%$ & 120 \\
\hline Cukup Baik (4) & 12 & $24 \%$ & 48 \\
\hline Baik (3) & 14 & $28 \%$ & 42 \\
\hline Tidak Baik (2) & 0 & $0 \%$ & 0 \\
\hline Sangat Tidak Baik (1) & 0 & $0 \%$ & 0 \\
\hline TOTAL & 50 & $100 \%$ & 210 \\
\hline
\end{tabular}

Data pada tabel diatas menunjukan bahwa pada butir pertanyaan 1 sebanyak $48 \%$ memberikan penilaian sangat baik atas kondisi gedung yang dimiliki oleh Pegadaian Syariah Caabang Veteran Purwakarta dengan skor 120. Sedangkan 24\% menilai cukup baik dengan skor 48 , dan $28 \%$ menilai baik dengan skor 42 .

Tabel 3.6

Usaha dalam Mempromosikan Pegadaian

\begin{tabular}{|c|c|c|c|}
\hline & Frekuensi & Persentase & Skor \\
\hline Sangat Baik (5) & 12 & $24 \%$ & 60 \\
\hline Cukup Baik (4) & 18 & $36 \%$ & 72 \\
\hline Baik (3) & 20 & $40 \%$ & 60 \\
\hline Tidak Baik (2) & 0 & $0 \%$ & 0 \\
\hline Sangat Tidak Baik (1) & 0 & $0 \%$ & 0 \\
\hline TOTAL & 50 & $100 \%$ & 192 \\
\hline
\end{tabular}

Pada butir pertanyaan 2 sebanyak 24\% responden memberikan penilaian sangat baik dengan skor 60 , sedangkan sebanyak $36 \%$ menilai cukup baik dengan skor 72 , dan $40 \%$ menilai baik dengan skor 60 .

Tabel 3.7

Penampilan Karyawan

\begin{tabular}{|c|c|c|c|}
\hline & Frekuensi & Persentase & Skor \\
\hline Sangat Baik (5) & 14 & $28 \%$ & 70 \\
\hline Cukup Baik (4) & 15 & $30 \%$ & 60 \\
\hline Baik (3) & 21 & $42 \%$ & 63 \\
\hline Tidak Baik (2) & 0 & $0 \%$ & 0 \\
\hline Sangat Tidak Baik (1) & 0 & $0 \%$ & 0 \\
\hline TOTAL & 50 & $100 \%$ & 193 \\
\hline
\end{tabular}

Pada butir pertanyaan 3 sebanyak $28 \%$ memberikan penilaian sangat baik dengan skor 70 . Sedangkan sebanyak $30 \%$ menilai cukup baik dengan skor 60 , dan $42 \%$ menilai baik dengan skor 63.

Dari ketiga butir pertanyaan diatas maka dapat diketahui jumlah skor nya adalah 595. Skor ideal dari dimensi Tangible (bukti fisik) adalah 750. Berdasarkan data tersebut maka tingkat kualitas pelayanan pada dimensi Tangible (bukti fisik) adalah 0.79 atau $79 \%$

2. Reliabiliti (Keandalan)

Tabel 3.8

Kemampuan melakukan Pelayan Tepat Waktu

\begin{tabular}{|c|c|c|c|}
\hline & Frekuensi & Persentase & Skor \\
\hline Sangat Baik (5) & $\overline{12}$ & $24 \%$ & 60 \\
\hline Cukup Baik (4) & 14 & $28 \%$ & 56 \\
\hline Baik (3) & 24 & $48 \%$ & 72 \\
\hline Tidak Baik (2) & 0 & $0 \%$ & 0 \\
\hline Sangat Tidak Baik (1) & 0 & $0 \%$ & 0 \\
\hline TOTAL & 50 & $100 \%$ & 188 \\
\hline
\end{tabular}

Pada butir pertanyaan 4 sebanyak 24\% memberikan penilaian sangat baik atas kemampuan karyawan Pegadaian Syariah Cabang Veteran Purwakarta dalam melakukan pelayanan teapat waktu dengan skor 60. Sedangkan $28 \%$ menilai cukup baik dengan skor 56 , dan $48 \%$ menilai baik dengan skor 72 .

Tabel 3.9 
EKSISBANK Vol. 2 No. 2 Desember 2018

Ketepatan Pegadaian dalam Memenuhi Janji

\begin{tabular}{|c|c|c|c|}
\hline & Frekuensi & Persentase & Skor \\
\hline Sapgat Baik (5) & 14 & $28 \%$ & 70 \\
\hline Cukup Baik (4) & 15 & $30 \%$ & 60 \\
\hline Baik (3) & 21 & $42 \%$ & 63 \\
\hline Tidak Baik (2) & 0 & $0 \%$ & 0 \\
\hline Sangat Tidak Baik (1) & 0 & $0 \%$ & 0 \\
\hline TOTAL & 50 & $100 \%$ & 193 \\
\hline
\end{tabular}

Pada butir pertanyaan 5 sebanyak 28\% memberikan penilaian sangat baik atas ketepatan Pegadaian Syariah Cabang Veteran Purwakarta dalam memenuhi janjinya dengan skor 70. Sedangkan $30 \%$ menilai cukup baik dengan skor 60 , dan $42 \%$ menilai baik dengan skor 63 .

Tabel 3.10

Kemampuan dalam memecahkan Masalah Nasabah

\begin{tabular}{|c|c|c|c|}
\hline & Frekuensi & Persentase & Skor \\
\hline Sangat Baik (5) & 13 & $26 \%$ & 65 \\
\hline Cukup Baik (4) & 14 & $28 \%$ & 56 \\
\hline Baik (3) & 23 & $46 \%$ & 69 \\
\hline Tidak Baik (2) & 0 & $0 \%$ & 0 \\
\hline Sangat Tidak Baik (1) & 0 & $0 \%$ & 0 \\
\hline TOTAL & 50 & $100 \%$ & 190 \\
\hline
\end{tabular}

Pada butir pertanyaan 6 sebanyak $26 \%$ responden memberikan penilaian sangat baik atas kemampuan yang dimiliki pihak Pegadaian Syariah Cabang Veteran Purwakarta dalam memecahkan masalah nasabah dengan skor 65 Sedangkan sebanyak $28 \%$ menilai cukup baik dengan skor 56 , dan $46 \%$ menilai baik dengan skor 69 .

Tabel 3.11

Pegadaian Tidak Pernah Melakukan Kesalahan dalam Pencatatan

\begin{tabular}{|c|c|c|c|}
\hline & Frekuensi & Persentase & Skor \\
\hline Sangat Biik (5) & 14 & $28 \%$ & 70 \\
\hline Cukup Baik (4) & 16 & $32 \%$ & 64 \\
\hline Baik (3) & 20 & $40 \%$ & 60 \\
\hline Tidak Baik (2) & 0 & $0 \%$ & 0 \\
\hline Sangat Tidak Baik (1) & 0 & $0 \%$ & 0 \\
\hline TOTAL & 50 & $100 \%$ & 194 \\
\hline
\end{tabular}

Pada butir pertanyaan 7 sebanyak $28 \%$ responden menilai sangat baik dengan skor 70 . Sedangkan sebanyak $32 \%$ menilai cukup baik dengan skor 64 , dan sebanyak $40 \%$ menilai baik dengan skor 60.

Berdasarkan hasil penelitian tingkat kualitas pelayanan pada dimensi Reliabiliti (keandalan) diketahui jumlah skornya adalah 765, dengan skor idealnya yaitu 1000. Maka tingkat kualitas pelayanan pada dimensi Reliabiliti (keandalan) adalah 0.765 atau $76.5 \%$.

3. Responsiveness (Daya Tanggap)
Tabel 3.12

Pegadaian Selalu bersedia Membantu Nasabah

\begin{tabular}{|c|c|c|c|}
\hline & Frekuensi & Persentase & Skor \\
\hline Sangat Baik (5) & 21 & $42 \%$ & 105 \\
\hline Cukup Baik (4) & 14 & $28 \%$ & 56 \\
\hline Baik (3) & 15 & $24 \%$ & 45 \\
\hline Tidak Baik (2) & 0 & $0 \%$ & 0 \\
\hline Sangat Tidak Baik (1) & 0 & $0 \%$ & 0 \\
\hline TOTAL & 50 & $100 \%$ & 206 \\
\hline
\end{tabular}

Pada butir pertanyaan 8 sebanyak $42 \%$ responden menilai sangat baik dengan skor 105. Sedangkan sebanyak $28 \%$ menyatakan cukup baik dengan skor 56, dan sebanyak $24 \%$ menyatakan baik dengan skor 45 .

Tabel 3.13

Pegadaian Tidak Menunjukkan Kesan Sibuk dalam Menyambut Nasabah

\begin{tabular}{|c|c|c|c|}
\hline & Frekuensi & Persentase & Skor \\
\hline Sangat Baik (5) & 10 & $20 \%$ & 50 \\
\hline Cukup Baik (4) & 15 & $30 \%$ & 50 \\
\hline Baik (3) & 25 & $50 \%$ & 75 \\
\hline Tidak Baik (2) & 0 & $0 \%$ & 0 \\
\hline Sangat Tidak Baik (1) & 0 & $0 \%$ & 0 \\
\hline TOTAL & 50 & $100 \%$ & 185 \\
\hline
\end{tabular}

Pada butir pertanyaan 9 sebanyak 20\% responden menilai sangat baik dengan skor 50. Sedangkan sebanyak $30 \%$ menilai cukup baik dengan skor 60 , dan sebanyak $50 \%$ menilai baik dengan skor 75 .

Tabel 3.14

Pegadaian akan Memberikan Pelayanan dengan Cepat Tanggap Kepada Nasabahnya

\begin{tabular}{|c|c|c|c|}
\hline & Frekuensi & Persentase & Skor \\
\hline Sangat Baik (5) & 14 & $28 \%$ & 70 \\
\hline Cukup Baik (4) & 14 & $28 \%$ & 56 \\
\hline Baik (3) & 22 & $44 \%$ & 66 \\
\hline Tidak Baik (2) & 0 & $0 \%$ & 0 \\
\hline Sangat Tidak Baik (1) & 0 & $0 \%$ & 0 \\
\hline TOTAL & 50 & $100 \%$ & 192 \\
\hline
\end{tabular}

Pada butir pertanyaan 10 sebanyak $28 \%$ responden menilai sangat baik dengan skor 70 . Sedangkan sebanyak $28 \%$ menilai cukup baik dengan skor 56 , dan sebanyak $44 \%$ menilai baik dengan skor 66.

Dari butir pertanyaan diatas dapat diketahui jumlah skor pada dimensi Responsiveness (daya tanggap) adalah 583. Skor idealnya adalah 750. Jadi tingkat kualitas pelayanan pada dimensi Responsiveness (daya tanggap) adalah 0,77 atau 77\%.

4. Assurance (Jaminan dan Kepastian)

Tabel 3.15 
EKSISBANK Vol. 2 No. 2 Desember 2018

Pegadaian Menanamkan Kepercayaan Kepada Karyawannya

\begin{tabular}{|c|c|c|c|}
\hline & Frekuensi & Persentase & Skor \\
\hline Sangat Baik (5) & 14 & $28 \%$ & 70 \\
\hline Cukup Baik (4) & 15 & $30 \%$ & 60 \\
\hline Baik (3) & 21 & $42 \%$ & 63 \\
\hline Tidak Baik (2) & 0 & $0 \%$ & 0 \\
\hline Sangat Tidak Baik (1) & 0 & $0 \%$ & 0 \\
\hline TOTAL & 50 & $100 \%$ & 193 \\
\hline
\end{tabular}

Pada butir pertanyaan 11 sebanyak $28 \%$ responden menilai sangat baik dengan skor 70 . Sedangkan sebanyak $30 \%$ menyatakan cukup baik dengan skor 60 , dan $42 \%$ menyatakan baik dengan skor 63 .

Tabel 3.16

Nasabah Merasa Aman dengan Transaksi yang Mereka Lakukan

\begin{tabular}{|c|c|c|c|}
\hline & Frekuensi & Persentase & Skor \\
\hline Sangat Baik (5) & 12 & $24 \%$ & 60 \\
\hline Cukup Baik (4) & 14 & $28 \%$ & 56 \\
\hline Baik (3) & 24 & $48 \%$ & 72 \\
\hline Tidak Baik (2) & 0 & $0 \%$ & 0 \\
\hline Sangat Tidak Baik (1) & 0 & $0 \%$ & 0 \\
\hline \multicolumn{2}{|c|}{ Tumber : Data Primer (Kuesioner) } \\
\hline
\end{tabular}

Pada butir pertanyaan 12 sebnayak $24 \%$ responden menyatakan sangat baik dengan skor 60 . Sedangkan sebanyak $28 \%$ menyatakan cukup baik dengan skor 56 , dan sebanyak $48 \%$ responden menyatakan baik dengan skor 72 .

Tabel 3.17

Karyawan Mempunyai Pengetahuan yang Memadai

\begin{tabular}{|c|c|c|c|}
\hline & Frekuensi & Persentase & Skor \\
\hline Sangat Baik (5) & 11 & $22 \%$ & 55 \\
\hline Cukup Baik (4) & 14 & $28 \%$ & 56 \\
\hline Baik (3) & 25 & $50 \%$ & 75 \\
\hline Tidak Baik (2) & 0 & $0 \%$ & 0 \\
\hline Sangat Tidak Baik (1) & 0 & $0 \%$ & 0 \\
\hline TOTAL & 50 & $100 \%$ & 186 \\
\hline
\end{tabular}

Pada butir pertanyaan 13 sebanyak $22 \%$ responden menyatakan sangat baik dengan skor 55. Sedangkan $28 \%$ responden menyatakan cukup baik dengan skor 56 , dan $50 \%$ responden menyatakaan baik dengan skor 75 .

Tabel 3.18

Karyawan Bersikap Sopan dan Ramah Kepada Nasabah

\begin{tabular}{|c|c|c|c|}
\hline & Frekuensi & Persentase & Skor \\
\hline Sangat Bpik (5) & 15 & $30 \%$ & 75 \\
\hline Cukup Baik (4) & 24 & $48 \%$ & 96 \\
\hline Baik (3) & 11 & $22 \%$ & 33 \\
\hline Tidak Baik (2) & 0 & $0 \%$ & 0 \\
\hline Sangat Tidak Baik (1) & 0 & $0 \%$ & 0 \\
\hline TOTAL & 50 & $100 \%$ & 204 \\
\hline
\end{tabular}

Pada butir pertanyaan 14 sebanyak 30\% responden menyatakan sangat baik dengan skor 75 . Sedangkan sebanyak $48 \%$ responden menyatakan cukup baik dengan skor 96 , dan sebnayak $22 \%$ responden menyatakan baik dengan skor 33 .

Berdasarkan hasil penelitian jumlah skor dari butir pertanyaan diatas aadalah 771, dengan skor idealnya yaitu 1000 . Maka tingkat kualitas pelayanan dilihat dari dimensi Assurance (jaminan dan kepastian) adalah sebesar 0.771 atau $77.1 \%$.

5. Empathi (Perhatian)

Tabel 3.19

Pegadaian dalam Memberikan Pelayanan kepada Nasabah tidak memandang status social

\begin{tabular}{|c|c|c|c|}
\hline & Frekuensi & Persentase & Skor \\
\hline Sangat Baik (5) & 24 & $48 \%$ & 120 \\
\hline Cukup Baik (4) & 11 & $22 \%$ & 44 \\
\hline Baik (3) & 15 & $30 \%$ & 45 \\
\hline Tidak Baik (2) & 0 & $0 \%$ & 0 \\
\hline Sangat Tidak Baik (1) & 0 & $0 \%$ & 0 \\
\hline TOTAL & 50 & $100 \%$ & 209 \\
\hline
\end{tabular}

Pada butir pertanyaan 15 sebanyak $48 \%$ responden menyatakan sangaat baik dengan skor 120. Sedangkan sebanyak $22 \%$ responden menyatakan cukup baik dengan skor 44, dan sebnayak $30 \%$ responden menyatakan baik dengan skor 45 .

Tabel 3.20

Pegadaian akan mengetahui minat dan kebutuhan nasabah

\begin{tabular}{|c|c|c|c|}
\hline & Frekuensi & Persentase & Skor \\
\hline Sangat Baik (5) & 10 & $20 \%$ & 50 \\
\hline Cukup Baik (4) & 19 & $38 \%$ & 76 \\
\hline Baik (3) & 21 & $42 \%$ & 63 \\
\hline Tidak Baik (2) & 0 & $0 \%$ & 0 \\
\hline Sangat Tidak Baik (1) & 0 & $0 \%$ & 0 \\
\hline TOTAL & 50 & $100 \%$ & 189 \\
\hline
\end{tabular}

Pada butir pertanyaan 16 sebanyak 20\% responden menyatakan sangat baaik dengan skor 50. Sedangkan sebanyak $38 \%$ responden menyatakan cukup baik dengan skor 76 , dan sebanyak $42 \%$ responden menyatakan baik dengan skor 63 . 
Tabel 3.21

Pegadaian mampu mengerti kebutuhan khusus dari nasabah

\begin{tabular}{|c|c|c|c|}
\hline & Frekuensi & Persentase & Skor \\
\hline Sangat Baik (5) & 12 & $24 \%$ & 60 \\
\hline Cukup Baik (4) & 18 & $36 \%$ & 72 \\
\hline Baik (3) & 20 & $40 \%$ & 60 \\
\hline Tidak Baik (2) & 0 & $0 \%$ & 0 \\
\hline Sangat Tidak Baik (1) & 0 & $0 \%$ & 0 \\
\hline TOTAL & 50 & $100 \%$ & 192 \\
\hline
\end{tabular}

Pada butir pertanyaan 17 sebanyak $24 \%$ responden menyatakan sangat baik dengan skor 60. Sedangkan sebanyak $36 \%$ responden menyatakan cukup baik dengan skor 72 , dan sebanyak 40\% responden menyatakan baik dengan skor 60 .

Dari butir pertanyaan diatas dapat diketahui jumlah skor dari dimensi Empathi (perhatian) adalah 590. Skor idealnya adalah 750. Jadi tingkat kualitas pelayanan pada dimensi Empathi (perhatian) sebesar 0.78 atau $78 \%$.

\section{G. Hasil Analisis Data}

Analisis pada data 50 nasabah Pegadaian Syariah Cabang Veteran Purwakarta yang menjadi responden dalam penelitian ini diketahui $52 \%$ terdiri dari pria dan $48 \%$ wanita dan sebagian besar berumur 30-39 tahun yakni mencapai 28\%, sedangkan untuk tingkat pendidikan terakhir sebagian besar adalah berpendidikan SMA mencapai 30\%, serta pekerjaan responden sebagian besar sebagai pedagang sebesar $30 \%$.

Salah satu dimensi kualitas pelayanan adalah Tangible (bukti fisik) yang terdiri dari 3 item pertanyaan meliputi gedung, promosi, dan pegawai. berdasarkan hasil penelitian bahwa gedung yang dimiliki oleh Pegadaian Syariah Cabang Veteran Purwakarta sudah cukup baik, hal itu dikarenakan lokasinya yang strategis sehingga mudah dijangkau oleh nasabah juga tempat yang bersih dan rapi sehingga nasabah merasa nyaman pada saat bertransaksi. Usaha pegadaian syariah dalam mempromosikan pegadaian yang dilakukan melalui karyawan, brosur, dan spanduk dengan menggunakan bahasa dan tutur kata yang baik. Selain itu penampilan karyawan yang rapi, sopan serta tidak menggunakan make up yang berlebihan membuat nasabah terkesan sehingga menarik minat nasabah untuk bertransaksi di Pegadaian Syariah Cabang Veteran Purwakarta. Dari hasil penelitian tingkat kualitas pelayanan nasabah Pegadaian Syariah Cabang Veteran Purwakarta dilihat dari dimensi tangible (bukti fisik) adalah 0.79 atau $79 \%$

Fasilitas yang diberikan dalam melakukan pelayanan akan terlihat semu tanpa adanya Reliabiliti (keandalan) dari pelaku bisnis. Keandalan dalam pelayanan dapat dilihat dari ketepatan waktu pada saat melakukan pelayanan sehingga nasabah tidak perlu menunggu terlalu lama, ketepatan dalam memenuhi janji secara akurat dan terpercaya. Selain itu juga keandalan dalam pelayanan dapat dilihat dari usaha dalam memecahkan masalah nasabah, dan ketelitian pada saat pencatatan. Tingkat kualitas pelayanan pada dimensi Reliabiliti (keandalan) adalah 0.765 atau $76.5 \%$ termasuk dalam kategori cukup baik.

Kualitas pelayanan juga dapat dilihat dari Responsiveness (daya tanggap) karyawan, yang mana karyawan selalu bersedia membantu nasabah dan tidak menunjukkan kesan sibuk pada saat menyambut nasabah yang ingin bertransaksi, serta memberikan pelayanan cepat tanggap menunjukkan pelaku bisnis yang profesional. Berdasarkan hasil penelitian pada dimensi Responsiveness (daya tanggap) adalah 0.77 atau $77 \%$ termasuk kategori cukup baik.

Adanya Assurance (jaminan dan kepastian) juga dapat menunjukkan nilai plus tersendiri bagi perusahaan terhadap pelayanan yang diberikan. Jaminan ini dapat ditunjukkan melalui rasa percaya, rasa aman dari bahaya dan resiko, pengetahuan yang memadai serta kesopansantunan yang diberikan karyawan kepada nasabah. Lain halnya pada dimensi Assurance (jaminan dan kepastian), dari penelitian yang dilakukan bahwasannya dimensi Assurance (jaminan dan kepastian) termasuk kategori cukup baik yaitu 0.771 atau $77.1 \%$

Selain empat hal diatas, kuyalitas pelayanan juga dapat dilihat dari faktor Empathi (perhatian) yang dapat diberikaan oleh karyawan kepada nasabahnya. Sikap empati ditunjukkan melalui kemudahan dalam melakukan hubungan dengan tidak memandang status sosial, komunikasi yang baik sehingga dapat mengetahui minat dan kebutuhan nasabah, mengerti kebutuhan khusus dari nasabahnya. Dari hasil olah data yang dilakukan, tingkat kualitas pelayanan pada Pegadaian Syariah Cabang Veteran Purwakarta ditinjau dari dimensi Empathi (perhatian) cukup baik yaitu 0.78 atau $78 \%$.

\section{KESIMPULAN}

Berdasarkan hasil penelitian dan pembahasan tentang Analisis Tingkat Kualitas Pelayanan Nasabah Pegadaian Syariah Cabang Veteran Purwakarta, maka dapat ditarik beberapa kesimpulan sebagai berikut :

1. Dari bukti fisik yang ada di Pegadaian Syariah Cabang Veteran Purwakarta masyarakat menganggap bahwa kondisi gedung yang dimiliki dan cara karyawan dalam berpenampilan sudah cukup baik, serta promosi yang dilakukan oleh pihak pegadaian sudah dapat menarik minat masyarakat untuk bertransaksi di pegadaian.

2. Keandalan pegadaian syariah dalam melakukan pelayanan tepat waktu dinilai sudah cukup baik, sebagian nasabah pun menyatakan puas. Selain itu pegadain syariah juga tidak pernah ingkar janji, dan selalu berusaha membantu memecahkan permasalahan yang dihadapi nasabahnya pada saat transaksi, serta selalu teliti dalam melakukan pencatatan data.

3. Daya tanggap pegadaian syariah merupakan kemauan untuk membantu dan memberikan pelayanan yang cepat dan tepat kepada nasabah, dengan penyampaian informasi yang jelas serta kesediaannya dalam menyambut nasabah dinilai nasabah Pegadaian Syariah Cabang Veteran Purwakarta sebagai hal yang dianggap paling penting dan mempunyai pengaruh yang paling dominan untuk meningkatkan kepuasan nasabah.

4. Jaminan dan kepastian yang diberikan pegadaian syariah cabang Veteran Purwakarta yaitu sifat karyawan yang dapat dipercaya, pengetahuan yang memadai mengenai masalah produk pegadaian syariah, serta sikap sopan karyawan pegadaian syariah terhadap nasabah yang ingin bertransaksi yang di nilai masyarakat sudah baik.

5. Perhatian yang diberikan oleh pegadaian syaariah cabang Veteran Purwakarta kepada nasabah pegadaian syariah mendapatkan respon yang baik. Nasabah menganggap bahwa pihak pegadaian mampu memberikan kemudahan dalam melakukan transaksi, dapat memahami kebutuhan nasabahnya, serta memberikan perhatian pribadi kepada nasabahnya.

Dari kelima dimensi pelayanan diketahui bahwa dimensi pelayanan yang dinilai paling baik menurut persepsi responden 


\section{EKSISBANK Vol. 2 No. 2 Desember 2018}

adalah dimensi Tangible (bukti fisik) yaitu mencapai $79 \%$. Sedangkan yang penilaiannya rendah menurut persepsi responden yaitu pada dimensi Reliabiliti (keandalan) yaitu sebesar $76.5 \%$

\section{REFERENSI}

[1] Abdurahman, Yahya (2012). Pegadaian dalam Pandangan Syariah Bogor: Al-Azhar Press.

[2] Ali, Muhammad (Anonimous). Kamus Lengkap Bahasa Indonesia Modern. Jakarta: Pustaka Amani.

[3] Ali, Zainudin (2008). Hukum Gadai Syariah. Jakarta: Sinar Grafika.

[4] Alma, Buchari (2009). Manajemen Bisnis Syarieah. Bandung: Alfabeta

[5] Hadi, Muhammad Sholikul (2003). Pegadaian Syariah, Jakarta: Salemba Diniyah

[6] Hakim Lukman (2012). Prinsip-Prinsip Ekonomi Islam, Jakarta Erlangga

[7] J Supranto (2011). Pengukuran Tingkat Kepuasan Pelanggan Untuk Menaikan Pangsa Pasar. Jakarta: PT Rineka Cipta.

[8] Kotler Philip dan Kevin Lane Keller (2009). Manajemen Pemasaran. Jakarta: Erlangga

[9] Muhammad (2007). Lembaga Ekonomi Syariecah. Yogyakarta: Graha Ilmu.

[10] Muslich Ahmad Wardi (2010). Fiqh Muamalat. Jakarta: Amzah.

[11] Sangadji Etta. M dan Sopiah (2013). Perilaku Konsumen. Yogyakarta: CV Andi.
[12] Soemitra Andri (2009). Bank dan Lembaga Keuangan Syariah. Jakarta: Kencana Prenada Group.

[13] Sugiyono (2008). Metodologi Penelitian Kuantitatif, Kualitatif Dan R\&D. Bandung: Alfabeta.

[14] Sugiono (2015). Metode Penelitian Kombinasi. Bandung: Alfabeta CV.

[15] Sukardi (2013). Metode Penelitian Pendidikan. Jakarta: PT Bumi Aksara.

[16] Syafe"i Rachmad (2001). Fiqh Muamalah, Bandung: Pustaka Setia.

[17] Syahida (2007). Qur"an Terjemah,Bandung: Quranidea.

[18] Tjiptono Fandy (2004). Manajemen Jasa. Yogyakarta: Andi.

[19] Umam Khaerul (2013). Manajemen Perbankan Syariah. Bandung: CV Pustaka Setia.

\section{SKRIPSI}

[20] Andi Lesmana (2008).Analisis Kepuasan Nasabah Terhadap Pelayanan Bank Mandiri (PERSERO) Tbk.(Skripsi tidak diterbitkan)

[21] Ahmad Khoiron (2010).Pengaruh kualitas pelayanan terhadap kepuasan nasabah pada Bank Syariah Mandiri cabang Malang.(Skripsi tidak diterbitkan)

[22] Yuliana A.Susanti (2011)Analisis Pengaruh Kualitas Pelayanan Terhadap Tingkat Kepuasan Pengguna Jasa Pada Bank Syariah Mandiri Cabang Salatiga.(Skripsi tidak diterbitkan)

\section{INTERNET}

[23] http://www.kajianpustaka.com/pengertian-faktor-dan-pengukurankepuasan-konsumen.html.(12 Oktober 2016 )

[24] https://www.mozaikislam.com/pegadaian-syariah.(12 Oktober 2016 )

[25] httpp://www.pegadaian.co.id. (12 Oktober 2016) 